\title{
Application of PCR-DGGE method for identification of nematode communities in pepper growing soil
}

\author{
Úng dụng phương pháp PCR-DGGE để định danh cộng đồng tuyến trùng trong \\ đất trồng hồ tiêu
}

Research article

\begin{abstract}
Nguyen, Thi Phuong ${ }^{1}$; Nguyen, Huu Hung ${ }^{1,3}$; Ha, Duy Ngo ${ }^{2}$; Duong, Duc Hieu ${ }^{3}$
${ }^{1}$ Nguyen Tat Thanh University, 300A Nguyen Tat Thanh, Dist.4, Ho Chi Minh City; ${ }^{2}$ Institute of Ecology and Biology Resources, VAST. 18 Hoang Quoc Viet, Cau Giay, Hanoi, Vietnam; ${ }^{3}$ Institute of Tropical Biology, Vietnam Academy of Science and Technology (VAST). 9/621 Hanoi highway, Linh Trung ward, Thu Duc district, HCM city, Vietnam
\end{abstract}

\begin{abstract}
Soil nematodes play an important role in indication for assessing soil environments and ecosystems. Previous studies of nematode community analyses based on molecular identification have shown to be useful for assessing soil environments. Here we applied PCR-DGGE method for molecular analysis of five soil nematode communities (designed as S1 to S5) collected from four provinces in Southeastern Vietnam (Binh Duong, Ba Ria Vung Tau, Binh Phuoc and Dong Nai) based on SSU gene. By sequencing DNA bands derived from S5 community sample, our data show 15 species containing soil nematode, other nematode and non-nematode (fungi) species. Genus Meloidogyne was found as abundant one. The genetic relationship of soil nematode species in S5 community were determined by Maximum Likelihood tree re-construction based on SSU gene. This molecular approach is applied for the first time in Vietnam for identification of soil nematode communities.
\end{abstract}

Tuyến trùng đất đóng vai trò chỉ thị quan trọng trong công tác đánh giá môi truờng và hệ sinh thái đất. Các nghiên cưu truớc đây đã cho thấy lợi ich của việc phân tích cộng đồng tuyến trùng đất bằng định danh sinh học phân tủ đối với việc đánh giá môi truờng đất. Ở đây, chúng tôi ứng dụng phuoong pháp PCR-DGGE dụa trên gene SSU để phân tích năm (ký hiệu tù S1 đến S5) cộng đồng tuyến trùng đất thuộc các vùng trồng chuyên canh cây hồ tiêu ở miền nam Việt Nam (Bình Dương, Bà Rịa Vũng Tàu, Bình Phước và Đồng Nai). Bằng cách giải trình tự các vạch của mẫu tuyến trùng $S 5$, kết quả cho thấy cộng đồng tuyến trùng này có 15 loài gồm nhóm tuyến trùng đất, nhóm các loại tuyến trùng khác và nhóm không phải tuyến trùng (nấm) và trong đó Meloidogyne là giống ưu thế. Mối quan hệ di truyền của các các loài tuyến trùng đất thuộc cộng đồng S5 được xác định bằng việc thiết lập cây phát sinh loài Maximum Likelihood dụa trên gene SSU. Đây là nghiên cứu đầu tiên ở Việt Nam sư dụng kỹ thuật PCR-DGGE để phân tích các cộng đồng tuyến trùng đất trồng hồ tiêu.

Keywords: PCR-DGGE, soil nematode, molecular identification, SSU rDNA, phylogeny.

\section{Introduction}

Nematodes are one of the most abundant metazoans on the Earth and particularly in marine, freshwater, and soil habitats (Mitreva et al., 2005; Boag and Yeates, 1998). Soil is an excellent habitat for nematodes, and $100 \mathrm{~g}$ of soil may contain several thousands of them (Háněl and Čerevková, 2010). They exhibit various feeding types, free-living bacterial and fungal feeders, or animal and plant parasites (Morise et al., 2012; Kushida, 2013), some of which can cause economic damage to cultivated plants. A variety of functional roles of nematodes have been defined but because of their importance to agriculture, much more is known about plant-parasitic nematodes than the other kinds of nematodes which are present in soil (Nguyen et al., 2005).

Identification of nematode species is necessary for study of ecology and environment. There are estimates of be- 
tween 40,000 and 10,000,000 species in the phylum Nematoda (Yeates et al., 2009; Blaxter et al., 1998), animal and plant parasites particularly. Nematode community analyses have been conducted for various soil environments in Vietnam. These analyses, however, were based on traditional morphological identification of nematodes under the microscope (Duong et al., 2014; Tran and Nguyen, 2011). Morphological identification to name species is not technically possible due to abundance, small size, and lack of expert knowledge of nematode. To date, DNA barcode is used as an effective tool to classify nematode for supporting morphological method to assess the community structure of soil nematodes. In recent progress in DNA barcoding, a limited number of studies in Vietnam on soil nematode community analyses have been reported. It is helpful for nematode identification if using barcode for molecular identification to support morphological method. To approach the molecular method, a genetic profile derived from the mitochondrial or nuclear genome has been used and considered potentials for nematode identification. Small subunit $r$ DNA $(S S U)$ genes have been proved to be great help and efficiently to use.

Several molecular fingerprinting systems have been proposed for nematodes, including restriction fragment length polymorphisms (RFLP), randomly amplified polymorphic DNA (RAPD), amplified fragment length polymorphisms (AFLP) and polymerase chain reaction (PCR)-denaturing gradient gel electrophoresis (DGGE). Each approach has its strong points but to use for taxon identification we have to pay attention to convenience and efficiency of method. Where, PCR-DGGE was proved that it was efficient and simple to implement for taxon classification of soil nematode community (Foucher et al., 2004). Some studies showed that PCR-DGGE method was used commonly in taxon identification of organism communities not only for soil nematode but also in microorganism field (Ercolini, 2004; Nguyen et al., 2004) and in health research (Laubscher et al., 1994). However, PCR-DGGE may show less detection sensitivity due to a large number of species in nematode community (Foucher et al., 2004; Kushida, 2013).

In this study, we approached and developed PCR-DGGE method to identify five soil nematode communities (designed as S1 to S5) collected from Southeastern Vietnam. SSU18A-SSU9R primer pair was applied for amplification of $S S U$ region (Okada and Oba, 2008; Okada, 2010). S5 nematode sample was used for DNA sequencing. Fifteen species containing soil nematode, other nematode and non-nematode (fungi) species were identified. We report here for the first time in Vietnam the use of PCRDGGE to identify taxon of soil nematode and this molecular system can be applied for supporting morphological method.

\section{Materials and methods}

\subsection{Nematode sampling}

Soil sampling date was based on dry and rainy seasons of Southern Vietnam, the first was in April 2013 and the second was in September 2013. Soil samples were collected in depth of 10-20 cm. Nematodes were extracted from soils collected from four provinces: S1 (Xuan Tho, Xuan Loc, Dong Nai, 400 individuals), S2 (Hoa Binh, Xuyen Moc, Ba Ria Vung Tau, 350 individuals), S3 (Phu Gieng, Bu Gia Map, Binh Phuoc, 300 individuals), S4 (Loc Tan, Loc Ninh, Binh Phuoc, 200 individuals), S5 (An Binh, Phu Giao, Binh Duong, 400 individuals) by sieving method. Nematodes in each sample were fixed in absolute ethanol and stored at $-20^{\circ} \mathrm{C}$ until use.

\subsection{DNA isolation}

Nematode samples were washed with distilled water and centrifuged at 13,000 rpm for 5 minutes to diminish ethanol. Samples then were washed and placed in tubes consisting of $200 \mu \mathrm{l}$ Lysis Buffer $(50 \mathrm{mM} \mathrm{KCl}, 10 \mathrm{mM}$ Tris$\mathrm{Cl} \mathrm{pH} 8.3,2.5 \mathrm{mM} \mathrm{MgCl}_{2}, 0.45 \% \mathrm{NP} 40$, and $0.45 \%$ Tween 20) (Derycke et al., 2009). Total DNA samples were prepared by lysing nematode communities with 200 mg glass beads (100 $\mu \mathrm{m}$ diameter) in Mini Beadbeater (Biospec) at $4800 \mathrm{rpm}$ for 10 minutes. Samples were then centrifuged at $13000 \mathrm{rpm}$ for 5 minutes. The supernatant was collected and DNA was purified by using Dneasy Blood and Tissue Kit (Qiagen) and quantified with Vision Spectrophotometer (Hoefer) at wavelength of $260 \mathrm{~nm}$.

\subsection{PCR-DGGE and DNA sequencing}

$S S U$ gene were amplified for PCR-DGGE by using primer pair SSU18A_5'-AAAGATTAAGCCATGCATG-3' and SSU9R(GC)_5'-AGCTGGAATTACCGCGGCTG $\underline{C G C C}$

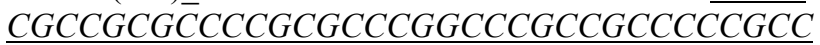
$\underline{C G}$-3' which contains GC-clamp (the underlined region) attached to 3 , end of SSU9R_5'AGCTGGAATTACCGCGGCTG-3' primer (Okada, 2010).

PCR was performed in $50 \mu 1$ reaction mixture containing $25 \mu \mathrm{l}$ PCR Master Mix (Thermo Scientific), $0.25 \mu \mathrm{M}$ of each primer, 1 unit of Taq enzyme (Qiagen), $1 \mu$ nematode DNA and distilled deionized water up to $50 \mu \mathrm{l}$. PCR was carried out in Surecyler 8800 (Agilent) with thermal cycles: initial denaturation at $95^{\circ} \mathrm{C}$ for 5 minutes, 30 cycles (denaturation at $95^{\circ} \mathrm{C}$ for 1 minute, annealing at $52^{\circ} \mathrm{C}$ for 1 minute, elongation at $72^{\circ} \mathrm{C}$ for 1 minute), the final extension step was at $72^{\circ} \mathrm{C}$ for 10 minutes. PCR products were checked by $2 \%$ agarose gel electrophoresis at voltage of $135 \mathrm{~V}$ for 20 minutes (Major Science).

DGGE was performed in Major Science Mini 300 apparatus. The denaturant gradient ranged from $20 \%$ to $50 \%$ (100\% denaturant contained $7 \mathrm{M}$ urea and $40 \%$ (v/v) formamide) with $6 \%$ poly-acrylamide gel. Electrophoresis was performed in $0.5 \mathrm{X}$ Tris-Acetate-EDTA (TAE) buffer at $60^{\circ} \mathrm{C}$ at $75 \mathrm{~V}$ for $8 \mathrm{~h}$. Subsequently, the gel was stained with SYBR Safe DNA gel stain (1:10,000 dilution; Invitrogen) in the dark for 45 minutes at room temperature. DNA were detected by UltraSlim LED illuminator (MaestroGen). Photos were taken by digital camera Canon Powershot ELPH 100HS. DNA bands were analyzed by Quantity One program. 
Eighteen DGGE bands derived from S5 sample were cut from the gel using distilled razor and placed in collection tubes. These tubes were then washed with distilled deionized water three times, added $\mathrm{ddH}_{2} \mathrm{O}\left(\mathrm{v}_{\mathrm{ddH} 2 \mathrm{O}}: \mathrm{w}_{\text {gel }}=2: 1\right)$ and then shaken in Thermal Shaker (Grant Bio) at $50^{\circ} \mathrm{C}$ and $1000 \mathrm{rpm}$ for $2 \mathrm{~h}$ to extract DNA from gel. Supernatant was collected and used for DNA amplification by PCR with primer pair SSU18A and SSU9R. PCR products were purified by PureLink PCR Purification Kit (Invitrogen) for sequencing by $1^{\text {st }}$ BASE company (Singapore).

\subsection{Identification and phylogenetic analysis}

SSU sequences were adjusted and multiply aligned using FinchTV v2.0, Annhyb v4.941, ClustalX v2.0. We used aligned sequences to identify nematode taxon using Basic Local Alignment Search Tool (BLAST) on NCBI (www.ncbi.nlm.nih.gov) databases.

Aligned sequences then were imported to MEGA v5.0 software to re-construct molecular phylogenetic tree based on Maximum Likelihood (ML) method and Neighbour-Joining and Maximum Parsimony methods with 500 bootstraps.

\section{Results and discussion}

\subsection{Analysis of $S S U$ gene by PCR-DGGE}

$S S U$ gene of five nematode communities was amplified for DGGE using PCR with primer pair SSU18A and SSU9R(GC) and checked in $2 \%$ agarose gel (data not shown). These PCR products were then applied for DGGE which has denaturant gradient ranged from $20 \%$ to $50 \%$ (Fig. 1). The results showed that all DNA bands concentrated in denaturant gradient ranged from $20 \%$ to $40 \%$. Each sample contains different number of bands and band intensity. Each band was considered to be specific for different species/genera.

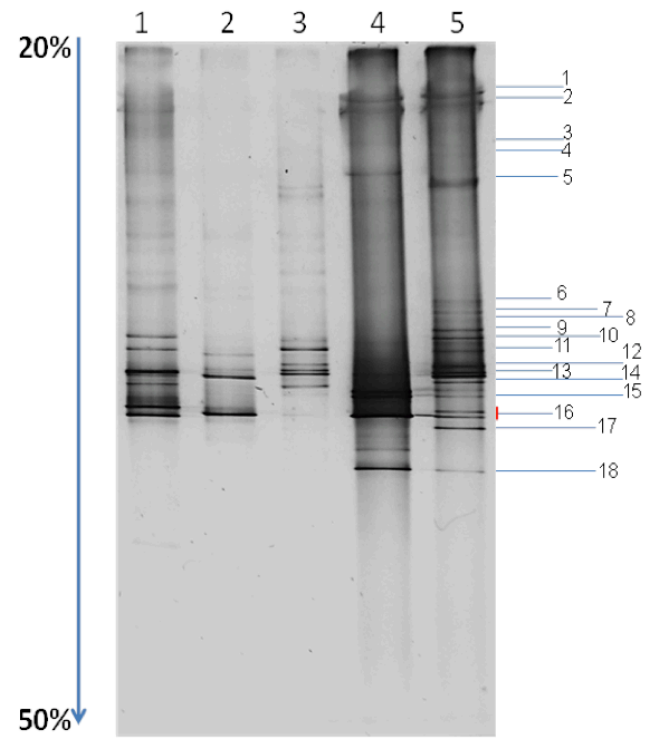

Figure 1. PCR-DGGE of five nematode communities. Well 1 to 5: sample S1 to S5. Denaturant gradient ranged from $20 \%$ to $50 \%$.
Table 1. Number of bands of five soil nematode communities

\begin{tabular}{lccccc} 
Nematode communities & S1 & S2 & S3 & S4 & S5 \\
\hline Number of DGGE bands & 17 & 11 & 13 & 14 & 18
\end{tabular}

S5 sample has higher number of bands than other sand clearly separated DNA bands for cutting (Table 1). So we would expect for the greatest number of nematode species in S5 sample. For those reasons, S5 was chosen for further analyzing soil nematode taxon.

S5 sample had 18 bands in DGGE gel. Most of these bands (6-18) concentrated in denaturant gradient ranged from $30 \%$ to $40 \%$ of gel (Fig. 1). Band 12 and 13 had strongest intensity indicating that species presented by these bands could be dominant species in S5 community. In contrast, band 3 and 4 had weakest but detectable intensity in DGGE gel indicating lower number of them in the soil sample.

The bands 1, 2, and 5 were blurred compare to other bands in gel and they seemed to be contaminations in DGGE process.

\subsection{Sequencing and molecular identification}

SSU bands in S5 sample were cut from DGGE polyacrylamide gel. DNA was extracted and amplified by PCR using primers SSU18A and SSU9R. PCR products then were purified by PureLink PCR Purification Kit. Visible PCR products were then sequenced.

BLAST analyses of SSUrRNA gene sequences shows that S5nematode community consists of 3 groups (Table 2).

Soil nematode group. Rotylenchulus reniformis (Band 7), Mylonchulus sigmaturus (Band 8), Dorylaimoides limnophilus (Band 9), Aglenchus agricola (Band 10), Meloidogyne arenaria (Band 12), Meloidogyne incognita (Band 13), Xiphinema elongatum (Band 15), Tylenchulus semipenetrans (Band 16), and Helicotylenchus multicinctus (Band 18) and fungivorous nematode: Aphelenchus avenae (Band 11). Bands 12 and 13, showing strongest intensity, were identified to as Meloidogyne arenaria and Meloidogyne incognita, respectively, which might present with the greatest number in S5 community.

Other nematode group: Pelodera cylindrica (Band 14) and Monoposthia costata (Band 17).

Non-nematode group: Schzophyllum radiatum (Band 3), Meyerozyma guilliermondii (Band 4) and Candida parapsilosis (Band 6).

SSU18A/SSU9R primer pair is commonly used for nematode community analysis (Okada, 2010). However, this primer pair produced PCR products that consisted of soil nematode, other nematode and non-nematode $S S U$ gene. Recently, Tyl2F-Tyl4R primer pair was designed based on the $18 \mathrm{SrRNA}$ gene and shown to be specific for plant parasitic and fungivorous nematodes. The number of detected species of plant parasitic and fungivorous nematodes and their DNA band intensity were much improved 
in comparison with SSU18A-SSU9R primers (Kushida, 2013). However, it was again not specific for only soil nematode. Our data and others indicate that other primers are required to be develop for better specificity.

\subsection{Molecular tree re-construction}

In order to define the genetic relationship of soil nematodes in S5 sample, ML method in MEGA v5.0 program was used to re-construct molecular tree based on $S S U$ gene. Molecular tree (Fig. 2) demonstrated two branches: Outgroup branch, Pelodera cylindrica and soil nematode branch, Rotylenchulus reniformis in a branch quite far from others and major branch consisted of two clades:

Clade A: Band 8, 9, 15 with identity less than 100\%, we used reference sequences in NCBI for molecular tree reconstruction to assess their relationships.

Table 2. List of organisms in S5 community identified by BLAST using SSU gene.

\begin{tabular}{|c|c|c|c|c|c|}
\hline \multirow{2}{*}{ BandNo. } & \multicolumn{3}{|c|}{ Closest species } & \multirow[b]{2}{*}{ Identity (\%) } & \multirow{2}{*}{ Accession No } \\
\hline & Soil nematode & Other nematode & Non-nematode & & \\
\hline 3 & & & Meyerozyma guilliermondii & 100 & KJ126853 \\
\hline 4 & & & Candida parapsilosis & 100 & EF568035 \\
\hline 6 & & & Schizophyllum radiatum & 100 & HE863742 \\
\hline 7 & Rotylenchulus reniformis & & & 100 & KP054069 \\
\hline 8 & Mylonchulus sigmaturus & & & 92 & AY284757 \\
\hline 9 & Dorylaimoides limnophilus & & & 92 & AY284829 \\
\hline 10 & Aglenchus agricola & & & 98 & KJ869357 \\
\hline 11 & Aphelenchus avenae & & & 99 & AY284639 \\
\hline 12 & Meloidogyne arenaria & & & 98 & KF112872 \\
\hline 13 & Meloidogyne incognita & & & 100 & KJ641552 \\
\hline 14 & & Pelodera cylindrica & & 96 & EU196021 \\
\hline 15 & Xiphinema elongatum & & & 95 & AY297824 \\
\hline 16 & Tylenchulus semipenetrans & & & 100 & AJ966511 \\
\hline 17 & & Monoposthia costata & & 96 & AY854221 \\
\hline 18 & Helicotylenchus multicinctus & & & 100 & FJ969124 \\
\hline
\end{tabular}

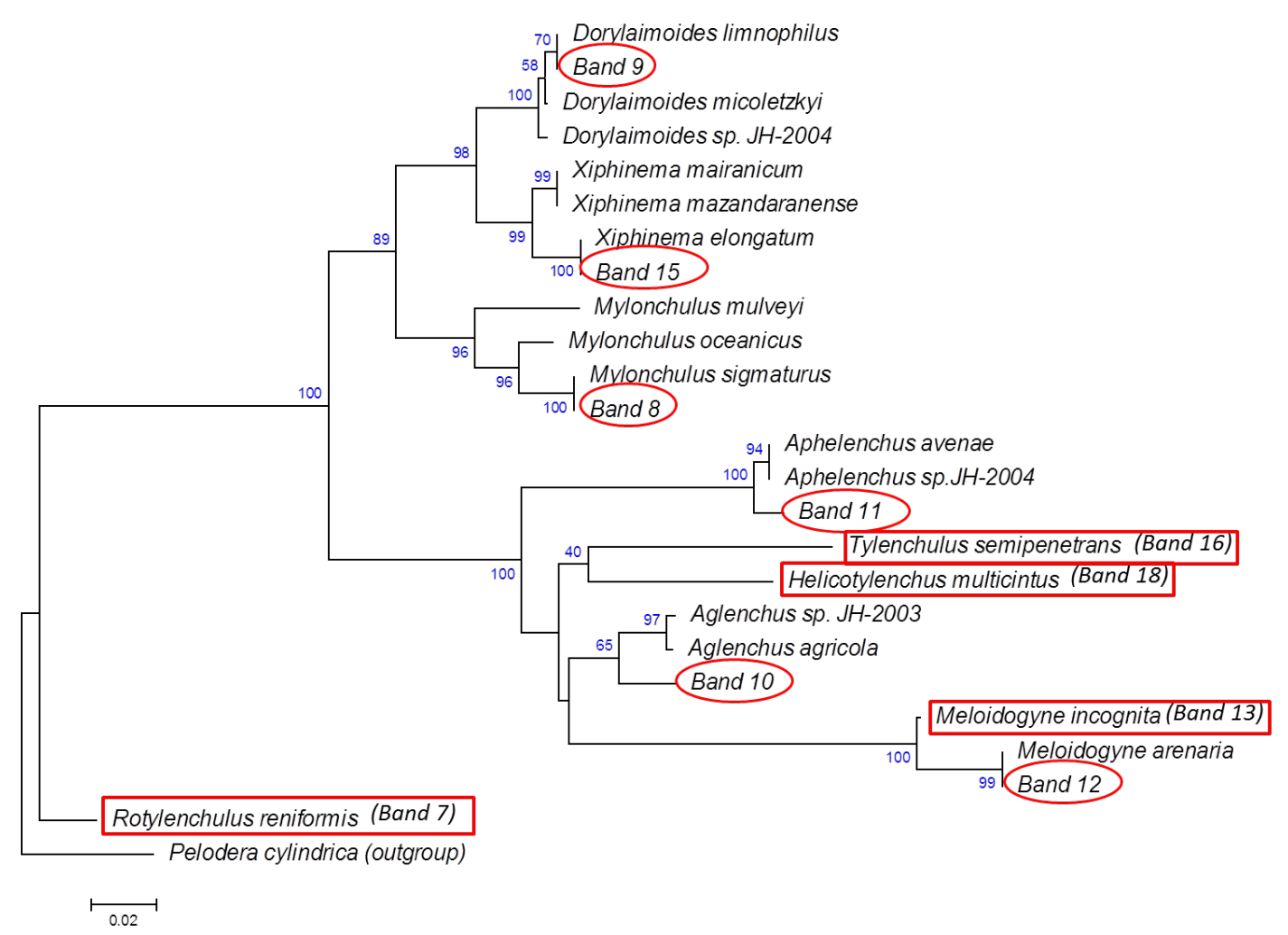

Figure 2. Maximum Likelihood phylogram based on soil nematode $S S U$ gene of $S 5$ community and reference organisms. Outgroup, Pelodera cylindrica. 500 bootstraps. Species in red circle are soil nematodes in S5 community. 
According to ML tree shown in Fig. 2, node "Band 8" is close to Mylonchulus sigmaturus (AY284757) node, and in the internal node consisted of Mylonchulus mulveyi (AB361448) and Mylonchulus oceanicus (AB361445) that belong to genus Mylonchulus. Therefore, Band 8 species may belong to genus Mylonchulus.

Node "Band 9" is close to Dorylaimoides limnophilus (AY284829) node, and in the internal node consisted of Dorylaimoides micoletzkyi (AY284830) and Dorylaimoides sp. JH-2004 (AY593951) that belong to genus Dorylaimoides. Therefore, Band 9 species may belong to genus Dorylaimoides.

Node "Band 15" is close to Xiphinema elongatum (AY297824) node and in the internal node consisted of Xiphinema mairanicum (EU477384), Xiphinema mazandaranense (HQ658630) that belong to genus Xiphinema. Therefore, Band 15 species may belong to genus Xiphinema.

Genus Dorylaimoides (containing Band 9) and genus Xiphinema (containing Band 15) both belong to Dorylaimida order, so that they form a node distinct from genus Mylonchulus (containing Band 8) belong to Monochida order. Species in these order form clade A in phylogenetic tree.

Clade B consisted of Band 10, 11, 12, 13, 16 and 18.

With $100 \%$ of identity, Rotylenchulus reniformis (Band 7), Meloidogyne incognita (Band 13), Tylenchulus semipenetrans (Band 16), Helicotylenchus multicinctus (Band 18 ), we used their $S S U$ sequences to re-construct the molecular tree.

With identity less than $100 \%$, in similar way as clade A analysis, we got Bands 12, 10 and 11 that may belong to genus Meloidogyne, Aglenchus and Aphelenchus, respectively.

As it showed in Fig. 2, Band 12 species has close genetic relation with Meloidogyne incognita (Band 13) and both belong to genus Meloidogyne and they formed a separate node. Genus Aglenchus, Helicotylenchus, Rotylenchulusand Meloidogyne belong to Tylenchida order, so they form a big node that distinct from genus Aphelenchus (Aphelenchida order), all of them form clade B separated from clade $\mathrm{A}$ in the tree.

\section{Conclusions}

This study has shown that PCR-DGGE method is potentially suitable for nematode community analysis. The method is simple and efficient to use in molecular identification study. However, SSU18A-SSU9R primer pair used in this study was not efficient enough for soil nematode identification since it amplified not only nematode $S S U$ genes but also fungal $S S U$ genes. Further investigation is therefore required to solve this problem.

Abundant plant parasitic nematodes observed in S5 soil belong to genus Meloidogyne that makes of two species
Meloidogyne incognita and Meloidogyne spp.. This identification might help for the study of Meloidogyne spp., root-knot nematode in Piper nigrum, that cause serious crop damage in Vietnam.

\section{Acknowledgement}

This study was carried out as part of the Project "Application of PCR-DGGE (Polymerase Chain ReactionDenaturing Gradient Gel Electrophoresis) technique for the identifying soil nematode diversity" funded by the Vietnam Academy of Science and Technology.

\section{References}

[1] Blaxter, M.L., De Ley, P., Garey, J.R., Liuk, L.X., Scheldeman, P., Vierstraete, A., Vanfleteren, J.R., Mackey, L.Y., Dorris, M., Frisse, L.M., Vida, J.T., Thomas, W.K. (1998). "A molecular evolutionary framework for the phylum Nematoda", Nature. 392, pp. 71-75.

[2] Boag, B., Yeates, G.W. (1998). "Soil nematode biodiversity in terrestrial ecosystems", Biodiversity and Conservation. 7, pp. 617-630.

[3] Derycke, S., De Ley, P., De Ley, I.T., Holovachov, O., Rigaux, A., Moens, T. (2009). "Linking DNA sequences to morphology: cryptic diversity and population genetic structure in the marine nematode Thoracostoma trachygaster (Nematoda, Leptosomatidae)", Zoologica Scripta. 39, pp. 276-289.

[4] Duong, D.H., Le, T.P.A., Bui, T.T.N., Ngo, X.Q., Nguyen, D.T., Nguyen, H.H., Nguyen, V.T. (2014). "Nematode communities act as bio-indicator of status and processes of an agricultural soil ecosystem in Thanh An, Binh Phuoc province", Journal of Vietnamese Environments. 6, pp. 227-232.

[5] Ercolini, D. (2004). "PCR-DGGE fingerprinting: novel strategies for detection of microbes in food", Journal of Microbiological Methods. 56, pp. 297314.

[6] Foucher, A.L.J.L., Bongers, T., Noble, L.R., Wilson, M.J. (2004). "Assessment of nematode biodiversity using DGGE of 18S rDNA following extraction of nematodes from soil", Soil Biology and Biochem, pp. 2027-2032.

[7] Foucher, A.L.J.L., Bongers, T., Noble, L.R., Wilson, M.J. (2004). "Assessment of nematode biodiversity using DGGE of 18S rDNA following extraction of nematodes from soil", Soil Biology \& Biochemistry. 36, pp. 2027-2032.

[8] Háněl, L., Čerevková, A. (2010). "Species and genera of soil nematodes in forest ecosystems of the Vihorlat Protected Landscape Area, Slovakia", Helminthologia. 47, pp. 123-135.

[9] Kushida, A. (2013). "Design and Evaluation of PCR Primers for Denaturing Gradient Gel Electrophoresis Analysis of Plant Parasitic and Fungivorous Nematode Communities", Microbes Environments. 28(2), pp. 269-274. 
[10] Laubscher, K.H., Glew, R.H., Lee, R.L., Okinaka, R.T. (1994). "Use of Denaturing Gradient Gel Electrophoresis to Identify Mutant Sequences in the pGBucocerebrosidase Gene", Human Mutation. 3, pp. 411-415.

[11] Mitreva, M., Blaxter, M.L., Bird, D.M., McCarter, J.P. (2005). "Comparative genomics of nematodes", TRENDS in Genetics. 21, pp. 573-581.

[12] Morise, H., Miyazaki, E., Yoshimitsu, S., Eki, T. (2012). "Profiling nematode communities in unmanaged flowerbed and agricultural field soils in japan by DNA barcode sequencing", PLoS ONE. 7(12), pp. 269-274.

[13] Nguyen, N.C, Phan, K.L., Trinh, Q.P., Moens, M. (2005). "Application of ITS-rDNA sequencing for identification of nematodes from Vietnam", In: Proceedings of $1^{\text {st }}$ National Workshop on Ecological and Biological Resources. Hanoi, 17 May 2005. Agriculture Publishing House, pp. 33-42. (Vietnamese and English summary)

[14] Nguyen, T.T., La, T.T.P., Dang, T.C.H. (2004). "Using denaturing gradient gel electrophoresis for detection of microbial community in toxic chemicals contaminated soils", Journal of Biotechnology. 2, pp. 381-388. (Vietnamese and English summary)

[15] Okada, H. (2010), "Technical Report on the PCRDGGE Analysis of Soil Nematode Community", $\mathrm{Na}$ tional Institute for Agro-Environmental Sciences, Japan

[16] Okada, H., Oba, H. (2008). "Comparison of nematode community similarities assessed by polymerase chain reaction-denaturing gradient gel electrophoresis (DGGE) and by morphological identification", Nematology. 10, pp. 689-700.

[17] Tran, T.T.H., Nguyen, T.T. (2011). "Study on the population and density of nematodes attacking black pepper in Cam Lo, Quang Tri", Journal of Science, Hue University. 67, pp.5-12. (Vietnamese and English summary)

[18] Yeates, G.W., Ferris, H., Moens, T., Van Der Putten, W.H. (2009). "The role of nematode in ecosystems" In: Wilson, M.J., Kakouli-Duarte, T. "Nematodes as environmental indicators”, CAB International, pp. $1-32$. 